integral del desarrollo ha sido su principal talón de Aquiles. Y no cabe duda, y esto se desprende a lo largo de toda la obra, que esta misma razón ha sido la que ha llevado a estos autores a desarrollar trabajos que contribuyan a reforzar los puntos flacos que amenazan al concepto de sostenibilidad, y en consecuencia, a la consecución de un desarrollo más equilibrado en nuestras ciudades y territorios.

Javier E. Quesada Lumbreras Profesor de Derecho Administrativo Universidad de Granada

\title{
GONZÁLEZ-VARAS IBÁÑEZ, Santiago.Juicio a un abogado incrédulo. Consuelos para los que un día perdieron un proceso. La aleatoriedad de la justicia como aleatoriedad de la vida misma. Editorial Givitas, Madrid enero 2016
}

Es un hecho que la resolución de los asuntos judiciales depende de un ejercicio de interpretación pudiendo ser distintas las soluciones. Ante ello este libro objeto de recensión no realiza obviamente crítica alguna, al considerarlo inevitable. Su objeto es en concreto, más bien, realizar una explicación del fenómeno. De la lectura del trabajo se deduce claramente que es esto lo que pretende el autor partiendo de que falta explicar esta realidad.

En este tema el problema, pues, no sería tanto la administración de justicia. El problema sería, por contrapartida, de tipo intelectual, de ausencia de una explicación convincente sobre el componente de aleatoriedad de la administración de justicia. Los juristas están inmersos en el Derecho analizando instituciones concretas, los jueces resolviendo como mejor pueden los casos que se les plantean, pero falta una explicación de todo ello, explicación necesaria ante la seriedad y envergadura del problema. Seriedad, ya que uno puede perder su patrimonio o su libertad por una interpretación. No es esto criticable, pero sí la ausencia de explicaciones para el justiciable afectado, sobre todo.

La justicia se ve en la necesidad de negar la aleatoriedad haciendo ver lo racional del juicio porque no podríamos aceptar que alguien tenga que asumir que por una interpretación se produzcan esas consecuencias, cuando son desfavorables. Pero lo cierto es que el problema queda sin resolver o explicar a poco que se profundice en ello. 
Todo esto estaba mejor explicado cuando la administración de justicia y el Derecho mismo se veían envueltos en criterios complementarios al racional, de autoridad o incluso religiosos porque eran una forma de explicar ese componente variable o interpretable o azaroso del juicio concreto. Sin embargo, la autosuficiencia de la explicación racional es el quid de las flaquezas del nuevo orden en ese plano explicativo que hace aguas a poco que se examine la cuestión. Por eso profundizando en ello el autor llega a la conclusión de que la única posibilidad de explicar este serio asunto está en la necesidad de buscar un nuevo complemento al Derecho para entender ese componente innegable de azar o no racional sino intuitivo o sensitivo. Y el autor lo ve en "el arte", después de hacer ver los límites de la psicología y la imposibilidad de un retorno a viejas explicaciones. Dejo así planteada la cuestión para que el lector acuda a la obra y observe los argumentos de González-Varas en este sentido.

Se entiende fácilmente, por tanto, el título del libro, ya que una explicación del fenómeno termina aportando "consuelos para los que un día perdieron un proceso": ante el "factor interpretación" se relativiza el alcance del significado de las sentencias. Y sobre el otro subtítulo, la cuestión es en principio clara: "la aleatoriedad de la justicia como aleatoriedad de la vida misma”, si bien el interés de González-Varas sería más antropológico que jurídico, es decir, extraer las consecuencias que del Derecho y la justicia se desprenden para la realidad humana y social. Este gran ejemplo que es la administración de justicia aporta mucho para aquello otro que más interesa.

El libro expone numerosos casos jurídicos que revelan ese factor de interpretación o azar inherente al Derecho, demostrando erudición en Derecho pero también en otras áreas no jurídicas. Se escribe en tono literario a modo de dos personajes cuyo nombre es expresivo de cuanto decimos: el "Sr. Intérprete" o juzgador y el "Sr interpretado" o justiciable que ha tenido la desdicha de caer en la red de lo interpretable.

Una obra que debería no pasar desapercibida en el debate de fondo del Derecho administrativo y el sentido y límites esenciales de las garantías del justiciable ante la jurisdicción contencioso-administrativa.

Dra. Inmaculada de la Fuente Cabero 